\title{
Root-restricting layers in German agricultural soils. Part II: Adaptation and melioration strategies
}

\author{
Florian Schneider • Axel Don (1)
}

Received: 14 February 2019/Accepted: 18 June 2019/Published online: 13 July 2019

(C) The Author(s) 2019

\begin{abstract}
Aims In many agricultural soils in Germany, elongation of deep roots is restricted by compactness, anoxia and acidity. This study examined the adaptation and melioration strategies of farmers who cultivate sites with such root-restricting layers (RRLs).

Methods The German Agricultural Soil Inventory was evaluated with respect to land use and crop rotations on sites with and without RRLs. The likelihoods of deep tillage, drainage and liming and the feasibility of biological melioration (bio-drilling) were predicted using soil, geology, climate and socioeconomic data.

Results Anoxic and acidic sites were preferentially used as grassland. Cropland with RRLs was often dominated by maize instead of wheat. About $54 \%$ of agricultural land in Germany was limed, 45\% drained, 6\% deep chiselled and 5\% deep ploughed. The abundance of biopores was positively related to silt content and $\mathrm{pH}$, but negatively related to rock content.

Conclusions Deep tillage is not very popular for alleviating soil compactness, but bio-drilling could be used to facilitate deeper rooting in loamy and well-aerated soils with low rock fragment contents and $\mathrm{pH}$ values $>5$.
\end{abstract}

Responsible Editor: W Richard Whalley.

Electronic supplementary material The online version of this article (https://doi.org/10.1007/s11104-019-04186-8) contains supplementary material, which is available to authorized users.

F. Schneider · A. Don $(\bowtie)$

Thünen Institute of Climate-Smart Agriculture, Bundesallee 65, 38116 Braunschweig, Germany

e-mail: axel.don@thuenen.de
Waterlogged soils could be meliorated by improved drainage and extreme acidity by enhanced liming practices. However, many farmers preferred grassland use as opposed to meliorating RRLs.

Keywords Subsoiling · Deep ripping · Earthworm burrow · Hardpan · Land improvement · Soil profile modification
Abbreviations
RMSE root mean square error
RRLs root-restricting soil layers
$\mathrm{R}^{2} \quad$ coefficient of determination
SOC soil organic carbon

\section{Introduction}

Root-restricting layers (RRLs) in agricultural soils can severely limit the plant availability of water and nutrients from subsoils. Restricted access to these subsoil resources can cause severe yield losses, especially in growing seasons with droughts (Kirkegaard et al. 2007). In Germany, the area extent of RRLs has recently been estimated to be $71 \%$ of total agricultural land (Schneider and Don 2019). Root restrictions were mainly of physical origin (soil strength, rock fragments, bedrock), but also physico-chemically derived (acidity, anoxia). Affected farmers may either accept and adapt to RRLs or aim to improve adverse growing conditions through soil melioration (Fig. 1). Adaptation to RRLs may manifest 
itself in land use or the choice of crop type. Adjusting land use to site conditions is common practice: fertile soil with high yield potential tends to be used intensively, e.g. as conventional cropland. RRLs have been shown to decrease the fertility and potentially attainable yield of agricultural land, thus agricultural land with RRLs might preferentially be used more extensively, e.g. as grassland. If sites with RRLs continue to be used as cropland, farmers might adjust crop rotations accordingly. Crop species have different requirements for soils. For example, winter wheat grows best in medium to heavy textured soil at $\mathrm{pH} 7$, while winter rye performs well on light textured soil and pH 5 to 6 (Goldhofer et al. 2014b). Thus if potential root restriction is caused by sandy subsoil texture or acidity, rye might be preferred over wheat.

Apart from adaptation, there are various melioration strategies for sites with RRLs. The choice of an appropriate meliorating option depends on the cause of root restriction. Anoxia is mostly caused by stagnant water or groundwater. Waterlogged soils can be drained by means of pipe or ditch systems. Successful drainage will improve the growing conditions and workability of affected sites. Root restrictions due to acidity can be overcome by liming. To meliorate acid subsoils with minimal disturbance, surface applications of gypsum have been found to be more effective than lime (Sumner 1995). This is because of the higher mobility of gypsum compared to lime. Leaching gypsum has been found to effectively supply calcium and decrease aluminium toxicity in acid subsoils (Shainberg et al. 1989). Compacted soil can be meliorated either biologically or physically. The biological method aims to promote the formation of earthworm and root channels penetrating compacted soil (Cresswell and Kirkegaard 1995). Subsequent crops could then use these biopores as highways into deeper soil layers (Kautz 2015). Taprooted cover crops can increase biopore density in soils (Han et al. 2015). The thicker the root, the greater its ability to elongate in compacted soil (Materechera et al. 1992). Most dicotyledonous plants form thicker roots than monocotyledons (Klepper 1992), therefore dicotyledons such as alfalfa have been suggested for meliorating compacted soil (Kautz 2015; Lynch and Wojciechowski 2015). A successful biological melioration of compacted soil is often cheaper and more persistent than physical melioration options (Shaxson and Barber 2003). The main disadvantage of meliorating compacted soil biologically is the time this management option requires: recuperation takes one to three years, during which the affected land has to be taken out of production. Physical melioration of compacted soil is much faster. Deep chiselling (= subsoiling or deep ripping) can loosen compacted soil layers mechanically down to $1 \mathrm{~m}$ depth (Schneider et al. 2017). However, mechanically loosened soil is susceptible to re-compaction. This re-compaction can be slowed down by decreasing trafficking intensity, particularly while soil is wet. The latter has often been neglected in the past, which may explain why many practitioners consider mechanical deep-loosening effects as short-lived while controlled field experiments, which avoided traffic and promoted biological stabilisation show that mechanical loosening can indeed be long-lived (Schneider et al. 2017). Traffic-induced re-compaction of loosened soil might be slowed down by incorporating compost and other organic matter-rich substrate into the subsoil (Frelih-Larsen et al. 2018; Jakobs et al. 2017). However, this management option is still in its test phase. Apart from mere soil loosening, soil profiles can also be ploughed, flipped or mixed up to $2 \mathrm{~m}$ depth to meliorate compacted subsoil layers. Such management options typically require large amounts of organic fertiliser and lime to replenish topsoil fertility after melioration (Bechtle 1985). This explains why ploughing, flipping or mixing of soil profiles are performed only rarely to overcome soil compactness. However, in New Zealand, soil flipping is successfully applied on large scales to remove ortsteinic hardpans in subsoils and improve water infiltration of soils under grassland use (Schiedung et al. 2019). Furthermore, in northwest Germany large regions were drained and deep ploughed several decades ago to convert former peatland and heathland into agricultural land (Alcántara et al. 2016).

Numerous strategies for managing sites with RRLs are in place and used differently depending on soil, environmental and socioeconomic conditions. However, there is no comprehensive overview of melioration measures that are applied in practice. In this study, the first German Agricultural Soil Inventory (Jacobs et al. 2018) was used to assess the popularity of common strategies for subsoil management in Germany. Specifically, the aims of this study were (i) to compare land use and characteristic crop types on sites with and without RRLs, (ii) to estimate the area extent of agricultural land with physicochemical melioration (deep tillage, drainage or liming), (iii) to examine the likelihood of physicochemical melioration based on pedologic, geologic, 


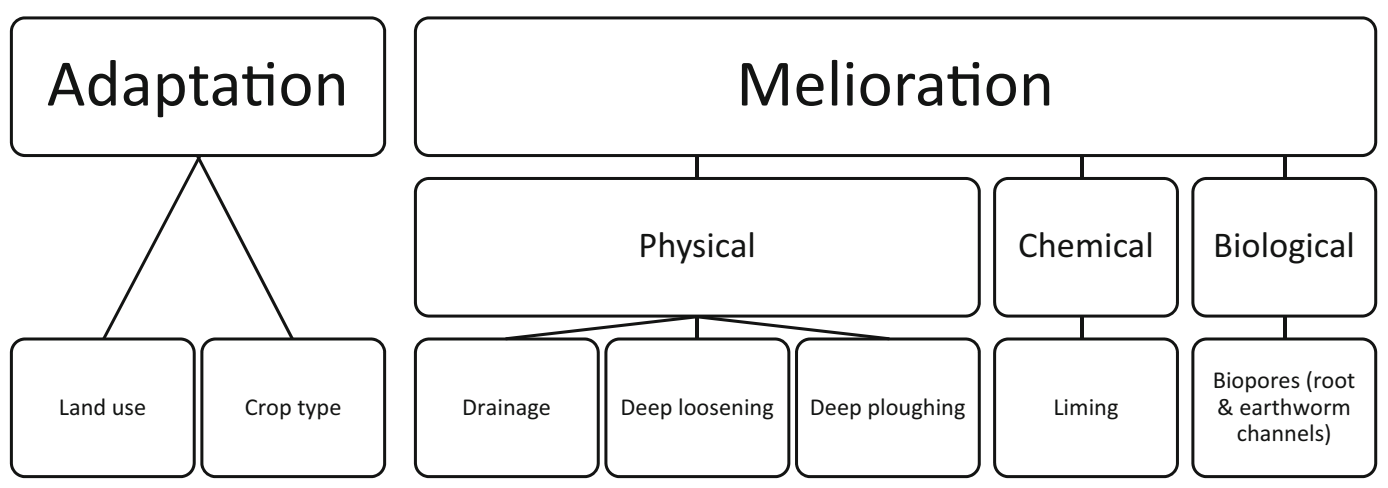

Fig. 1 Management strategies for cultivating land with root-restricting soil layers

climatic and socioeconomic characteristics, and (iv) to identify pedogenic constraints to meliorating compacted subsoil layers by earthworm and root channels.

\section{Materials and methods}

The dataset

The dataset of the first German Agricultural Soil Inventory (2011-2018) contains information on soil, geology, land use and management of 3078 sites covering German agricultural land in a $8 \mathrm{~km} \times 8 \mathrm{~km}$ grid (Jacobs et al. 2018). At each sampling site, soil profiles were dug to $100 \mathrm{~cm}$ depth. The soil profiles were characterised based on AD-HOC-AG Boden (2005) and soil samples analysed for soil organic carbon (SOC), total nitrogen (N), total inorganic carbon (TIC), rock fragment content, texture, $\mathrm{pH}_{\mathrm{H} 2 \mathrm{O}}$ (soil:water = 1:5), bulk density and electric conductivity (soil: water $=1: 5$ ). Soil profiles were described per soil horizon, while composite soil samples for laboratory analysis were taken at fixed depth intervals $(0-10,10-30,30-50,50-70$ and 70 $100 \mathrm{~cm}$ ). If a horizon boundary was at least $5 \mathrm{~cm}$ above or below a sampling depth boundary, an additional soil sample was taken. This allowed laboratory and field data to be merged. Based on Schneider and Don (2019), the following properties were assumed to restrict root growth: (i) consolidated, non-diggable bedrock, (ii) rock fragment contents $>75$ vol.- $\%$, (iii) cementation (ortstein or other cemented soil structure), (iv) compactness (packing densities $>1.75 \mathrm{~g} \mathrm{~cm}^{-3}$ ), (v) sandy subsoil (>95\% sand in $>30 \mathrm{~cm}$ depth), (vi) anoxia (reducing soil horizon), and (vii) acidity $\left(\mathrm{pH}_{\mathrm{H} 2 \mathrm{O}}<5\right)$. In sites with at least one RRL, potential rooting was classified as restricted, while at those sites without any RRL rooting it was regarded as not restricted.

Adapting to root-restricting soil layers

To assess the adaptation of land use to RRLs, the grassland fraction of agricultural land [\%] was calculated per cause of root restriction (acidity, anoxia, sandy subsoil, compactness, cementation, rock fragments, bedrock or none) and each fraction compared to the total grassland fraction independent of RRLs. Grassland was defined as agricultural land that has been used as such for at least five consecutive years (EU 2013).

Then the study looked specifically at cropland and compared crop types on sites with RRLs to those on sites without RRLs. This comparison was based on the share of $\mathrm{crop}_{i}$ in the crop rotation, i.e. the sum of years each site was used for crop $_{i}$ divided by the total number

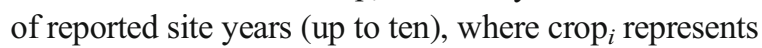
one of the five most common crop types: winter wheat (Triticum aestivum L.), maize (Zea mays L.), winter barley (Hordeum vulgare L.), canola (Brassica napus L.) and winter rye (Secale cereale L.). Information on site-specific land use and crop rotations was derived from farmer questionnaires.

Meliorating root-restricting layers physically or chemically

Sites were identified that have been physically (drainage, deep chiselling or deep ploughing) or chemically (liming) meliorated, and the extent examined to which the observed melioration measures were explained by site-specific soil properties, geology, geography, land use and other management practices. A detailed overview of the explanatory variables used to predict 
soil melioration is presented in Table S1. Information on physical and chemical site meliorations were primarily derived from farmer questionnaires. Drainage was defined as the anthropogenic removal of excess water from soil profiles via either pipe or trench drains. Deep chiselling was defined based on Schneider et al. (2017) as an annual or irregular form of tillage, which aims to loosen (and not flip or mix) soil to greater depths than annual ploughing or, in cases where cropland was not ploughed, to $>30 \mathrm{~cm}$ depth. Fields were counted as deep chiselled if there was at least one documented deep chiselling event in ten years prior to sampling. If farmers did not provide data on the exact year of chiselling, it was assumed that this occurred also in the ten years prior to sampling (4\% of deep chiselled fields). Deep ploughing was defined as a single or irregular (not annual) ploughing treatment, which flips soil layers to greater depths than the normal depth of annual tillage (average depth $31 \pm 0.1 \mathrm{~cm}$ ) with the aim of subsoil melioration (Schneider et al. 2017). At $29 \%$ of deep ploughed sites, the year of deep ploughing was dated (oldest: 1934; youngest: 2015; average year: 1988), at $15 \%$ of deep ploughed sites farmers were not sure about the year of deep ploughing, and at the remaining $56 \%$ of deep ploughed sites, farmers were not aware that the site which they managed was once deep ploughed (historic deep ploughing only identified by soil profile descriptions). Liming was defined as the application of calciumrich and/or magnesium-rich materials at least once in the ten years prior to sampling. If melioration data were not available in the questionnaires, an attempt was made to fill the respective gaps with information from site and profile descriptions from the field workers. However, in the case of drainage and liming, some gaps remained, leaving $85 \%$ and $87 \%$ of all sites for evaluation, respectively. The extent to which observed melioration measures could be explained with the variables listed in Table S1 was examined using Random Forest models (Breiman 2001). For each melioration measure (drainage, deep chiselling, deep ploughing and liming), one Random Forest Classification model was trained. Each model was trained to predict the probability of melioration at a given site. Probabilities $>50 \%$ were classified as meliorated and probabilities $<=50 \%$ as not meliorated. The accuracy of each model (classifier) was assessed using tenfold cross-validation with random fold assignments. A comparison of predicted and observed classes produced four possible outcomes: (i) sites were correctly classified as meliorated (true positives, TP), (ii) sites were correctly classified as not meliorated (true negatives, TN), (iii) sites were falsely classified as meliorated (false positive, FP), or (iv) sites were falsely classified as not meliorated (false negative, FN). Based on these four possible outcomes, sensitivity (= true positive rate, hit rate or recall) and specificity metrics were calculated as follows: sensitivity $=\mathrm{TP} /(\mathrm{TP}+\mathrm{FN})$ and specificity $=\mathrm{TN} /(\mathrm{TN}+\mathrm{FP})$. Additionally, for each classifier, the area under its corresponding receiver operating characteristics (ROC) curve was calculated as implemented in the caret package (Kuhn 2018). ROC curves depict trade-offs between the sensitivity and specificity of classifiers (Fawcett 2006). The area under an ROC curve (AUC) provides a robust metric that can be used to compare the overall performance of classifiers (Kuhn and Johnson 2013). In theory, AUC values can range from 0 (false prediction in all cases) to 1 (correct prediction in all cases). In practice, AUC values typically range between 0.5 (random guess) to 1 (correct prediction of all cases). In the original dataset, all melioration measures were imbalanced, i.e. the number of meliorated and not meliorated sites differed. Such class imbalances can have a strong negative impact on model fitting (Kuhn and Johnson 2013). In this study, subsampling of the training data was applied within cross-validation resampling as implemented in the caret package (Kuhn 2018) to overcome class imbalances. The following subsampling techniques were tested and evaluated against classifiers built without subsampling: down-sampling, up-sampling and two hybrid methods (ROSE by Menardi and Torelli (2014) and SMOTE by Chawla et al. (2002)). Based on the AUC, subsampling increased the performance of all melioration classifiers significantly, with down-sampling performing best, i.e. producing the highest AUC values. Therefore, all melioration classifiers discussed below were built using down-sampling.

Biopore abundance

Biopores were defined according to Kautz (2015) as continuous, round-shaped soil voids formed by plant roots and anecic earthworms. In the German Agricultural Soil Inventory, the abundance of root and earthworm channels was recorded separately at profile walls following AD-HOC-AG Boden (2005). Ordinal abundance classes recorded for each soil horizon were converted to a continuous scale using conversion factors (detailed description in Supplementary Material). As field workers who 
collected biopore data reported difficulties in separating root channels from earthworm burrows, the abundances of root channels and earthworm burrows were summed and evaluated together as biopores. Biopore abundance in $30-50 \mathrm{~cm}, 50$ $70 \mathrm{~cm}, 70-100 \mathrm{~cm}$ and $30-100 \mathrm{~cm}$ (total) was predicted using Random Forest Regression models based on all features listed in Table S1. Like the binary classifiers described in the previous section, the biopore model was also evaluated using crossvalidation. However, folds were not chosen at random but per field worker. In total, eight different field workers covered $89 \%$ of all sites. Thus, the dataset was divided into $8+1$ (for all other field workers) $=9$ folds. Each fold covered between 235 and 651 sites. This target-oriented cross-validation was chosen in order to account for potential bias in evaluating biopore data collected by different field workers. To evaluate the accuracy of the biopore model, its root mean square error (RMSE) and coefficients of determination $\left(\mathrm{R}^{2}\right)$ based on target-oriented cross-validation were reported. AUC was not suitable for evaluating the biopore model because the former is only applicable for classification and not for regression problems.

\section{Statistics}

Data analysis was conducted in RStudio v 1.1.456 (RStudio Team 2016) and R v 3.5.1 (R Core Team 2018). To build Random Forest models (classification and regression), the caret::train function (Kuhn 2018) was used in combination with party::cforest (Hothorn et al. 2005; Strobl et al. 2008; Strobl et al. 2007). Each Random Forest model consisted of 500 trees and the mtry-parameter was set to the square root of the number of predictor variables (Hastie et al. 2009). Variable importance was calculated in accordance with Breiman (2001). Those variables of greater importance than expected from a theoretical model where all variables are equally important were considered influential (Hobley et al. 2015). The effect of influential explanatory variables on targets was illustrated using partial dependence plots, which were computed using the pdp::partial function (Greenwell 2017). Spider charts were created with fmsb::radarchart (Nakazawa 2018) and all other figures using ggplot2 (Wickham 2016).

\section{Results}

Adaptation to root restrictions

Sites with root restrictions due to anoxia, acidity, rock content and/or bedrock were preferentially used as grassland (Fig. 2). Preferential grassland use was particularly pronounced at sites with anoxic subsoils due to groundwater or low $\mathrm{pH}$ values, where grassland use was $100 \%$ and $69 \%$ above the national average respectively. At sites with sandy subsoils and/or cemented soil structure, the proportion of grassland was similar to the national average. On agricultural land with root restrictions attributed to compactness, grassland use was below average.

Crop rotations differed significantly depending on the nature of RRLs (Fig. 3). On sandy, cemented, acidic and/or anoxic sites, the share of winter wheat was 36-70\% lower than on average croplands in Germany. Instead of winter wheat, farmers often chose to grow maize: maize cultivation was $61-105 \%$ above average on sandy, cemented, acidic and/or anoxic sites. On cropland with shallow bedrock and/or high rock fragment contents, maize and winter rye were under-represented, while winter barley and canola were more common than on average croplands. In contrast, winter rye was largely over-represented on sites with sandy subsoils, cemented and/or acid soil layers.

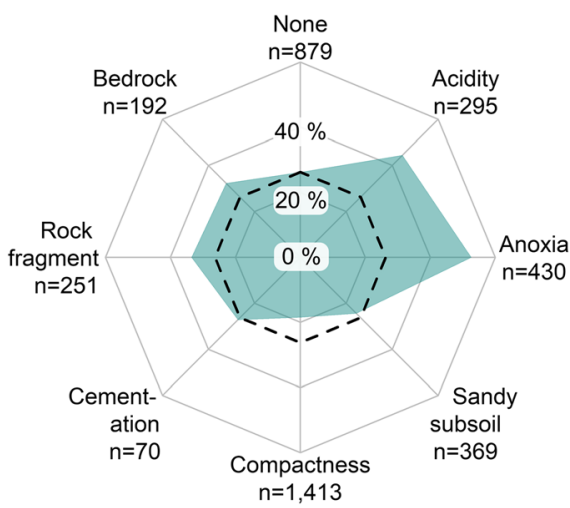

Fig. 2 Grassland fraction of total agricultural land (green polygon) per root-restricting property. The dashed line illustrates the proportion of grassland from total agricultural land $(26 \%)$. If the green polygon is outside the dashed circle, grassland use is higher than on average agricultural soils. " $n$ " gives the total number of sites per root-restricting property 
Fig. 3 Share of the five most common crop types in crop rotations per root-restricting property (yellow polygons). Dashed lines illustrate the share of a given crop in crop rotations of all sites - independent of rootrestricting properties. If the yellow polygon is outside the dashed circle, the abundance of a given crop is higher than on average agricultural soils. "n" gives the total number of sites per rootrestricting property
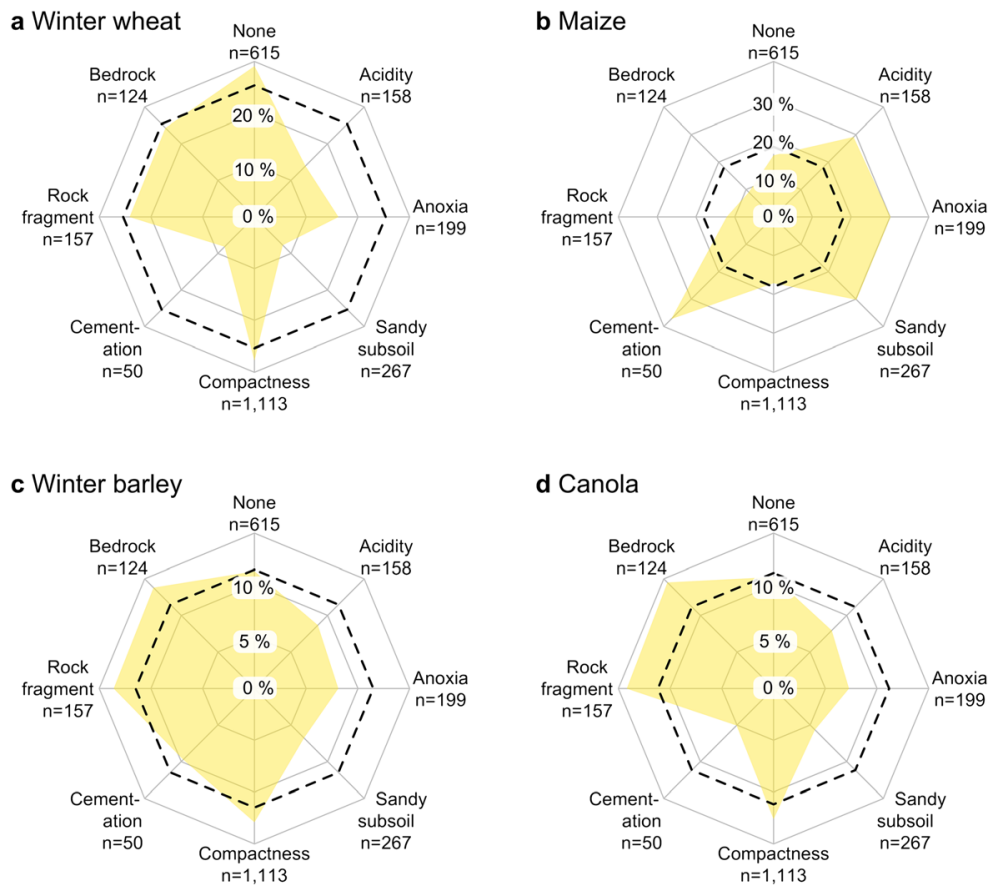

Physical and chemical melioration of root-restricting layers ${ }^{1}$

Liming was the most popular management option examined in this study, with $54 \%$ of sites being limed (Fig. 4). Liming probabilities were predicted with high accuracy $(A U C=0.84)$. Land use was the most important feature in predicting the likelihood of liming. About $66 \%$ of cropland was limed. The likelihood of liming increased with the share of canola, sugar beet and/or leguminous crops in rotations. In grassland, liming was much

\footnotetext{
${ }^{1}$ The geographic position of administrative regions, cities and rivers, which are discussed in this and the following sections, is illustrated in a supplementary map (Fig. S2).
}

less common than in cropland. Only $22 \%$ of grassland was limed. The presence of geogenic or pedogenic carbonates decreased the likelihood of liming by half. In carbonate-free soil, regional differences were more important in explaining lime applications than soil $\mathrm{pH}$. Liming was particularly common in northern Germany (latitude), where agricultural soil contained less clay and showed lower electrical conductivities than in southern Germany, which had less frequent liming. Hence, administrative and soil climate regions were also important in explaining lime applications.

After liming, drainage was the second most popular management option examined in this study, with $45 \%$ of sites being drained. Machine 
Fig. 4 Physical and chemical melioration of German agricultural land. Left: Map of soil melioration measures documented in the German Agricultural Soil Inventory. Right: Performance and variable importance of Random Forest models trained to predict the likelihood of soil melioration. Model performances were characterised by (i) the area under the curve (AUC) metric, which may range from 0.5 (random guess) to 1 (perfect fit), (ii) the number of correctly predicted meliorated sites divided by the total number of meliorated sites (sensitivity), and (iii) the number of correctly predicted nonmeliorated sites divided by the total number of non-meliorated sites (specificity)

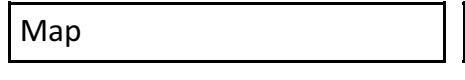

\section{Model results}

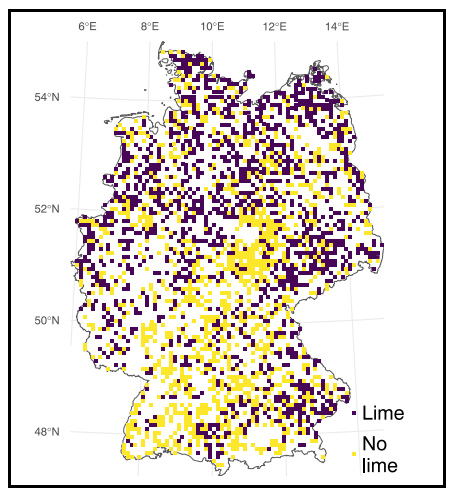

Model performance Variable importance (\%)

AUC: $0.84 \quad \frac{\text { Land use (23) }}{1 .}$

Sensitivity: 0.78 2. Canola, beet and legumes (18)

Specificity: 0.76 3. TIC (12)

4. Administrative region (10)

5. Soil climate (9)

6. Maize (7)

7. Latitude (6)

8. Soil region (5)

9. Clay (4)

10. Soil parent material (3)

11. EC (2)

12. $\mathrm{pH}(2)$

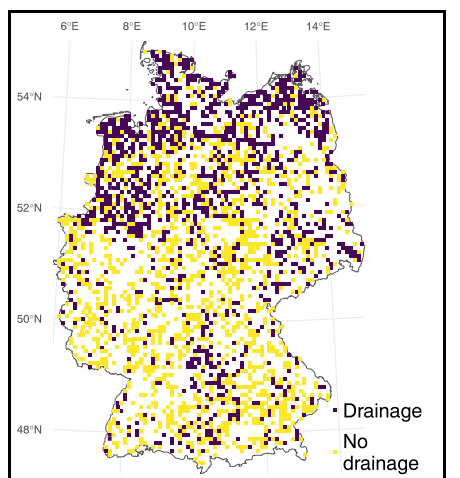

\begin{tabular}{|lll|}
\hline Model performance & \multicolumn{2}{l|}{ Variable importance (\%) } \\
\cline { 3 - 3 } SUC: 0.83 & Sensitivity: 0.76 & Reductomorphic features (14) \\
Specificity: 0.76 & 2. & Administrative region (12) \\
& 3. & Groundwater (11) \\
& 4. & Oximorphic features (11) \\
& 5. & Soil climate (10) \\
& 6. & Soil region (9) \\
& 7. & Latitude (8) \\
& 8. & RRL: anoxia (6) \\
& 9. & Soil parent material (5) \\
& 10. & Stagnogleyic horizon (4) \\
& 11. & Slope (3) \\
& 12. & Field size (3) \\
13. & Geomorphology (3) \\
14. & Soil order (2) \\
& \\
\end{tabular}
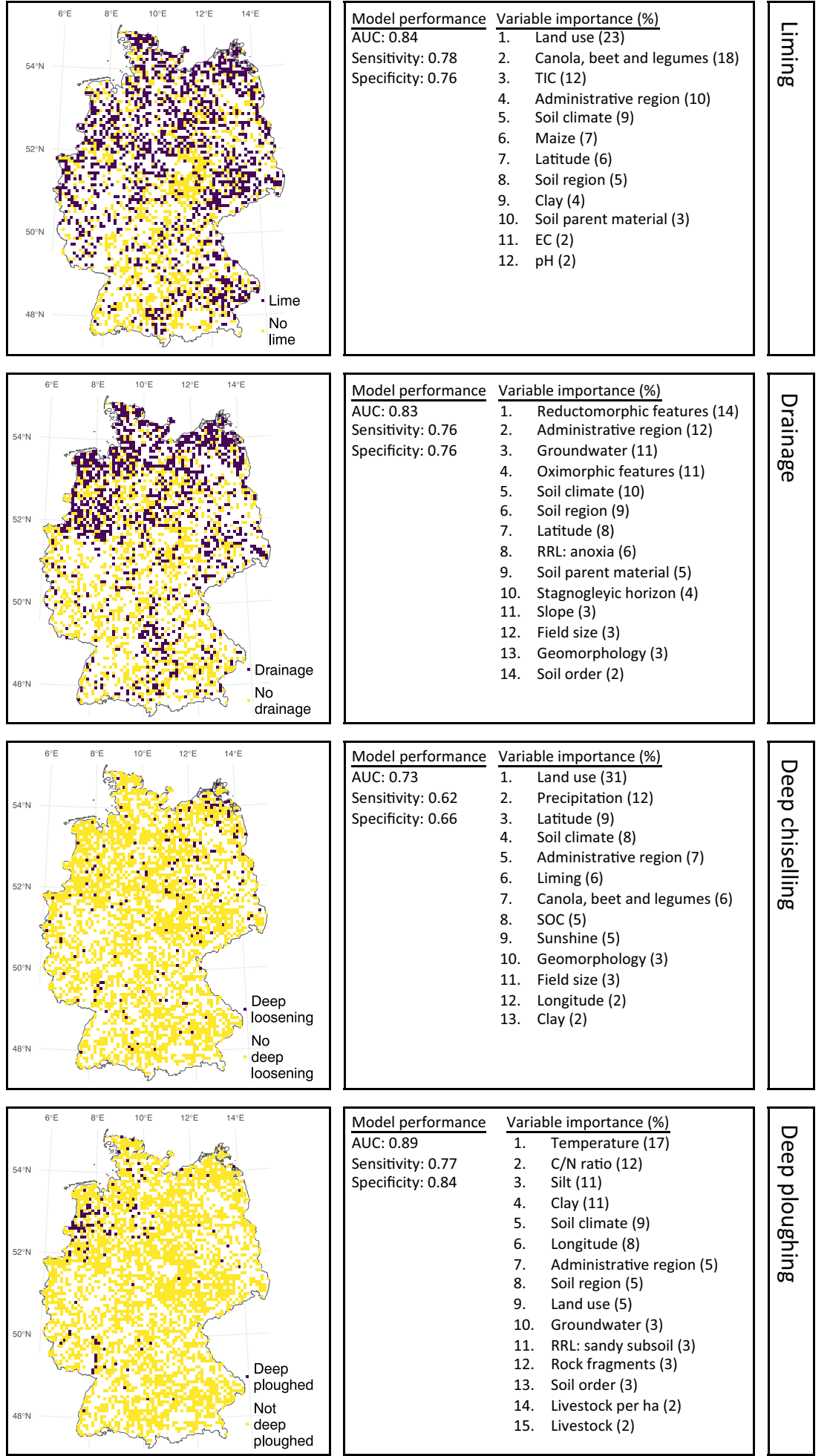

\begin{tabular}{|lll}
\hline Model performance & & Variable importance (\%) \\
\cline { 3 - 3 } AUC: 0.73 & Sensitivity: 0.62 & Land use (31) \\
Specificity: 0.66 & 2. & Precipitation (12) \\
& 3. & Latitude (9) \\
& 4. & Soil climate (8) \\
& 5. & Administrative region (7) \\
& 6. & Liming (6) \\
& 7. & Canola, beet and legumes (6) \\
& 8. & SOC (5) \\
& 9. & Sunshine (5) \\
& 10. & Geomorphology (3) \\
& 11. & Field size (3) \\
& 12. & Longitude (2) \\
13. & Clay (2)
\end{tabular}
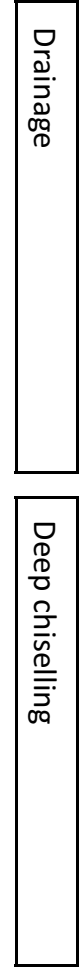

\begin{tabular}{|c|c|}
\hline \multirow{2}{*}{$\frac{\text { Model performance }}{\text { AUC: } 0.89}$} & Variable importance (\%) \\
\hline & Temperature (17) \\
\hline Sensitivity: 0.77 & $\mathrm{C} / \mathrm{N}$ ratio (12) \\
\hline Specificity: 0.84 & 3. Silt (11) \\
\hline & 4. Clay (11) \\
\hline & 5. Soil climate (9) \\
\hline & 6. Longitude (8) \\
\hline & 7. Administrative region (5) \\
\hline & 8. Soil region (5) \\
\hline & Land use (5) \\
\hline & 10. Groundwater (3) \\
\hline & 11. RRL: sandy subsoil (3) \\
\hline & 12. Rock fragments (3) \\
\hline & 13. Soil order (3) \\
\hline & 14. Livestock per ha (2) \\
\hline & 15. Livestock (2) \\
\hline
\end{tabular}


learning performed well in predicting the likelihood of drainage (AUC $=0.83$; Fig. 4). In contrast to liming, drainage was independent of land use. Instead, the degree of anoxia (reductomorphic features, depth of groundwater table, stagnogleyic horizon, semi-terrestrial soil order) and relict anoxia (oximorphic features) were most important in predicting the likelihood of drainage. Waterlogged soils occurred mostly in northern Germany, hence the classifier considered administrative regions (Lower Saxony, Schleswig Holstein, Mecklenburg Western Pomerania) and latitude (north) as important for predicting the likelihood of drainage. Drainage was preferentially performed at sites with morainic soil parent material, low slopes and large field size located in lowlands (geomorphology). Different causes of waterlogging, i.e. groundwater (Lower Saxony, coastline along the North Sea) or stagnant water (coastline along the Baltic Sea, Saxony, central southern Germany), were only of minor importance in explaining drainage. In total, $63 \%$ of Gleysols and 69\% of Stagnosols under agricultural use were drained.

Deep chiselling was much less common within ten years prior to sampling ( $6 \%$ of all sites) than liming or drainage activities. In contrast to the melioration measures described above, model performance was only moderate for deep chiselling (AUC $=0.73$ ). As for liming, land use was the most important variable for explaining deep chiselling. Most (99\%) deep chiselling was conducted on cropland. Eight percent of annual crops and $15 \%$ of perennial crops were deep chiselled. It was slightly more popular in eastern Germany, hence the likelihood of deep chiselling depended on administrative regions and other features that differed between eastern and western Germany: mean annual precipitation (low), sunshine duration (high), clay and SOC contents (both low) and field size (large). Furthermore, deep chiselling was preferentially conducted at sites that were flat and received regular lime applications.

About $5 \%$ of agricultural soils were deep-ploughed at least once before sampling. Deep-ploughed sites were clustered mostly in northwest Germany and to a minor extent in viticultural areas along the valleys of the Rhine (between Karlsruhe and Mainz) and Mosel (between Trier and Koblenz). In northwest Germany, most deepploughed sites showed high $\mathrm{C} / \mathrm{N}$ ratios, high sand contents, low rock contents and high groundwater tables.
Furthermore, deep-ploughed sites in north-west Germany were characterized by relatively mild winter temperatures and high animal stocking rates. Deep ploughing by land use followed the order permanent crops (30\%), annual crops (4\%) and grassland (3\%). The relatively high share of deep-ploughed soil under permanent crops was due to the popularity of deep ploughing in the viticulture of the Rhineland Palatinate. The Random Forest algorithm grasped these patterns well and predicted deep ploughing with the greatest accuracy of all melioration measures examined in this study $(\mathrm{AUC}=$ 0.89 ).

\section{Biopores}

Biopores composed on average about $2.3 \pm 0.04,1.7 \pm$ 0.03 and $1.1 \pm 0.03$ vol- $\%$ of the soil matrix in $30-50$, 50-70, and 70-100 $\mathrm{cm}$ depth respectively. However, there were significant regional differences related to physicochemical soil properties (Fig. 5, Fig. S3). Most biopores were found along the coast of the Baltic Sea, in the loess belt of central Germany, and in the alpine foreland south of the Danube river. In sandy soils, which cover large parts of Lower Saxony and Brandenburg, no or few biopores occurred. The Random Forest model trained to predict biopore densities of subsoils performed relatively poor: $\mathrm{R}^{2}$ ranged from 0.16 to 0.22 depending on depth increments (Fig. 6). This can likely be attributed to considerable random error in the biopore estimates due to conversion from ordinal to continuous scale. Nonetheless, the model identified meaningful input variables as important. Silt content was most important for predicting the share of biopores: the more silt, the more biopores there were. Rock fragments, however, decreased the share of biopores in soils. Furthermore, biopore abundance increased with soil $\mathrm{pH}$, clay content, $\mathrm{SOC}, \mathrm{C} / \mathrm{N}$ ratio (only in $30-50 \mathrm{~cm}$ depth) and increasingly dark soil colour, i.e. decreasing Munsell value (only in 50-100 cm depth). There was no evidence for land-use effects on biopore abundance in subsoils.

\section{Discussion}

\section{Adaptation to root restrictions}

At sites with RRLs due to anoxia, acidity, rock fragments and shallow bedrock, grassland use was above average. However, this preferential grassland use might 
Fig. 5 Biopore abundance in German agricultural soils at 30 $50 \mathrm{~cm}$ depth

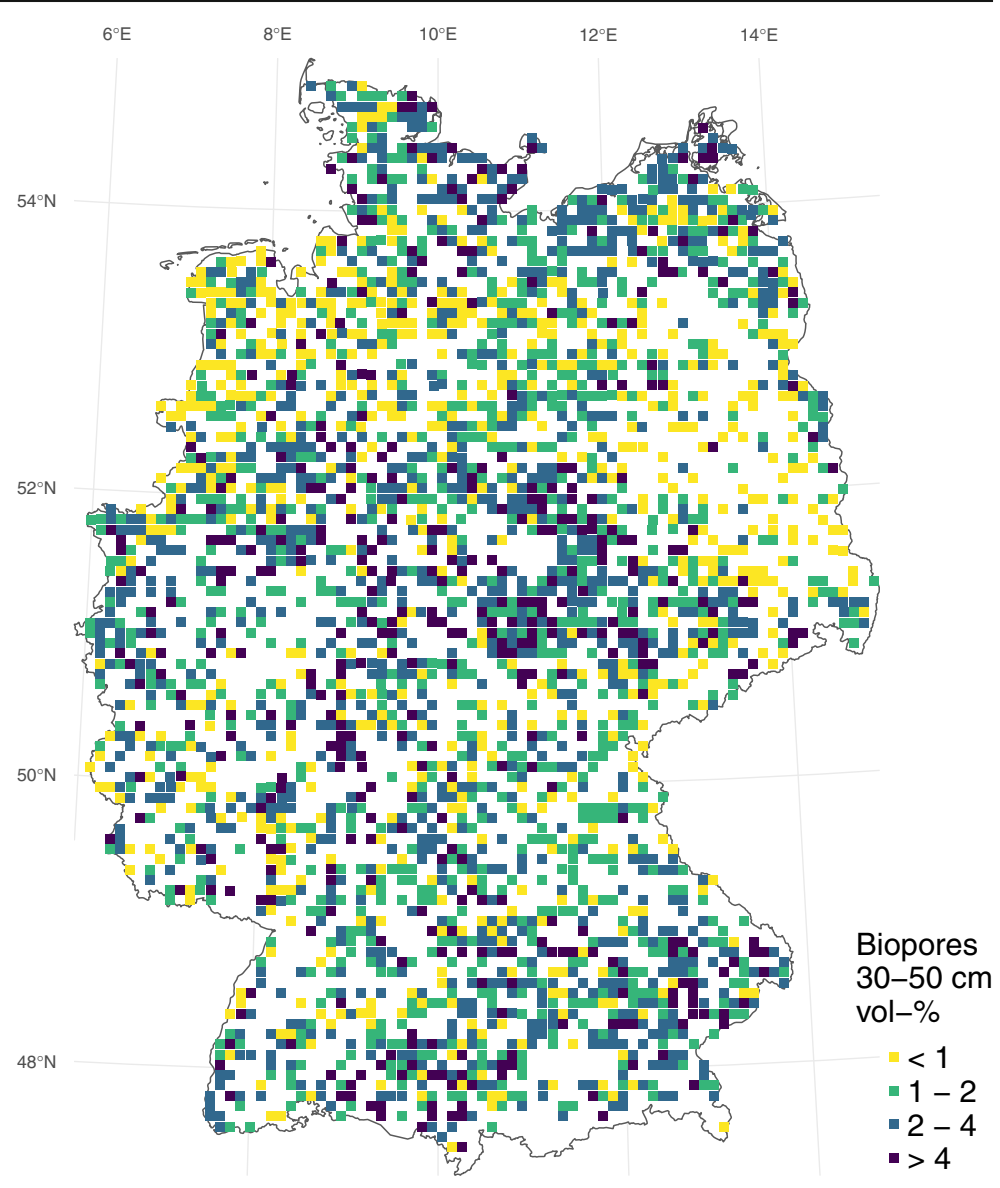

be explained by lower yield potentials due to RRLs (Schneider and Don 2019). Nevertheless, the workability of soil has to be considered when discussing the effect of soil quality on land use. Diepolder et al. (2014) attributed preferential grassland use of Gleysols to challenges in trafficking soils with high groundwater
Fig. 6 Significant predictors of the abundance of biopores in mineral soils by depth. Areas are proportional to the relative importance of the predictors. Each model is characterised by the number of observations in the training data ("n") and errors from tenfold cross-validation (root mean square error ("RMSE") and coefficients of determination $\left.\left(" \mathrm{R}^{2 "}\right)\right)$ ). Positive marginal effects of continuous predictors on biopore abundance are illustrated as "+" and negative effects as "-"
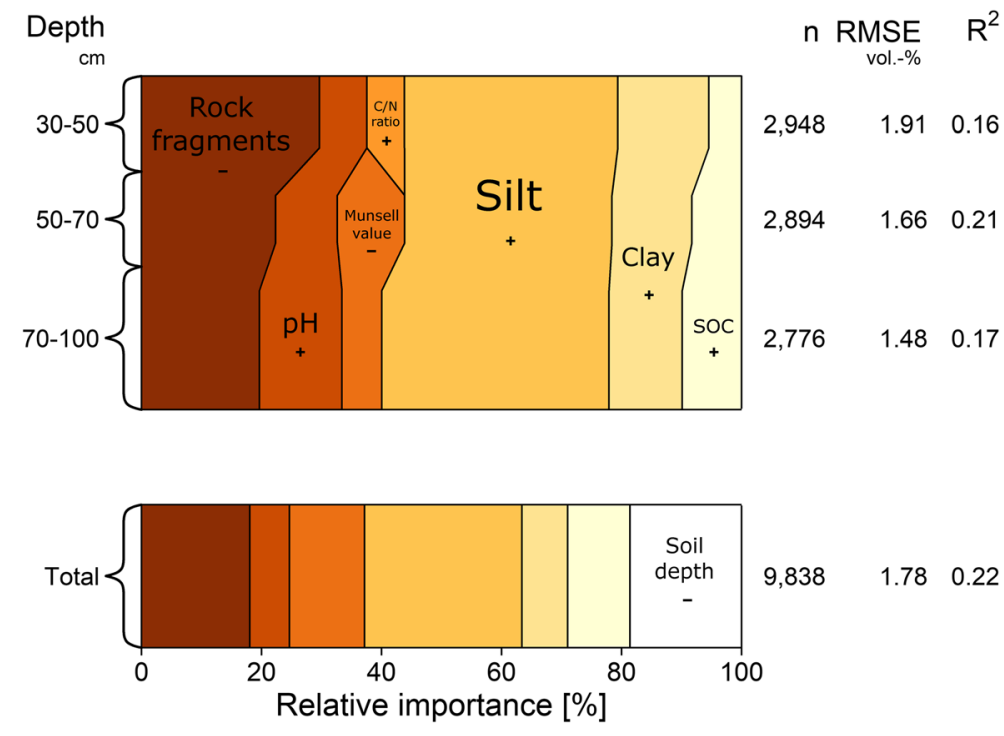
tables. Rock fragments hinder tillage practices and the preparation of seedbeds, while shallow bedrock can render ploughing impossible. However soil quality is just one of many factors influencing land use. Land use is also governed by socioeconomic drivers such as market demand, subsidies, infrastructure, alternative livelihoods to farming and demography (van Vliet et al. 2015). Such socioeconomic drivers might explain why on sites with lower yield potential due to sandy or cemented soil layers, land use did not differ from the national average. On compacted sites, grassland use was below average. This can be explained by cropland useinduced soil compaction (Schneider and Don 2019), and not vice versa. Moreover, most productive cropland soils with a high silt content (Luvisols) are also prone to subsoil compaction due to pedogenic lessivation.

In cropland with RRLs due to sandy subsoils, high groundwater tables, acidity and/or cementation, winter wheat and canola were under-represented, while maize and winter rye were over-represented (Fig. 3). This is in line with the typical requirements of these crops (Goldhofer et al. 2014b). Rye is generally regarded as the least demanding cereal crop planted in Germany with respect to pedogenic and climatic stressors (Goldhofer et al. 2014b). Rye tolerates acidic soil and periodically stagnant water much better than winter wheat and canola. Furthermore, rye typically roots relatively deeply, which makes it more drought-tolerant in sandy soil than wheat (Goldhofer et al. 2014b). The pedological niche of maize is similar to that of rye (Goldhofer et al. 2014b).

Physical and chemical melioration of root-restricting layers

Liming was the most popular melioration option examined in this study. However, in order to meliorate soils with root restrictions due to $\mathrm{pH}$ values $<5$ ( $10 \%$ of all sites), future lime quantities should exceed current application rates (Jacobs et al. 2018). As the surface application of lime may take years to leach through the soil column (Tang et al. 2003), amelioration of acid subsoils can be increased by applying more soluble gypsum minerals (Shainberg et al. 1989). Lime could also be applied directly in the subsoil if combined with deep chiselling. Such deep placements of lime in loosened furrows have been shown to typically reach only $<20 \%$ of the subsoil volume (Schmid et al. 1972). Despite the distribution problem of lime in subsoils, Richard et al.
(1995) reported a positive crop yield response to deep placements of lime in compacted and acidic subsoil. During the German Agricultural Soil Inventory, no evidence was found of deep placements of lime. However, liming popularity depended strongly on land use: although soil under grassland tends to be more acidic than under cropland use, only relatively few grasslands $(22 \%)$ were limed. This is in agreement with farmer extension services who recommend lower $\mathrm{pH}$ values for grassland than for cropland (Wendland et al. 2014).

Drainage proved to be a highly popular measure in meliorating both Gleysols (lowering the groundwater table) and Stagnosols (drainage of stagnant water). Characterising the degree of anoxia was of primary importance for predicting the likelihood of drainage, which occurred mostly in anoxic soils. This might seem contradictory since successful drainage decreases the degree of anoxia, and not vice versa. However, the following two reasons can explain the positive correlation between the degree of anoxia and likelihood of drainage: (i) drainage is performed only at sites with high degrees of anoxia, and (ii) to predict the likelihood of drainage, the degree of anoxia down to $1 \mathrm{~m}$ depth was characterised but most farmers drain their land to $<1 \mathrm{~m}$ depth (Patt and Gonsowski 2011). Drainage to $40-80 \mathrm{~cm}$ is sufficient to allow grazing (Diepolder et al. 2014) and draining to 80-100 cm for trafficking on cropland (Patt and Gonsowski 2011). Yield losses attributed to anoxia (Schneider and Don 2019) do not seem to justify the cost of draining agricultural land more deeply.

Deep chiselling was slightly more common in eastern Germany than in western Germany. This can partially be explained historically because in the former German Democratic Republic, subsoil melioration techniques were promoted on a large scale (Lindner et al. 1972; Renger 1974). However, today's farm structures may also favour deep chiselling activities in eastern Germany. Since German Reunification in 1990, most agricultural production cooperatives have been privatised (BMWi 2018; Wilson 1996) and today most agricultural land belongs to large farms that generate relatively high revenues (BMEL 2017). Considering the high costs of deep chiselling, today's farmers in eastern Germany might be more willing to adopt deep chiselling due to their greater financial power. Climatic factors can also be used to explain the popularity of deep tillage in eastern Germany: soil needs to be sufficiently dry during 
deep chiselling in order to shatter and not smear, and eastern Germany tends to be drier than western Germany. When predicting the likelihood of melioration, it was interesting that the model for deep chiselling performed worse (lower AUC value) than models for other physicochemical melioration measures. This indicates that, apart from environmental and socioeconomic (field sizes, farm size and type etc.) features, farmer idiosyncrasy (family traditions and individual beliefs) plays an important role in the adoption of deep chiselling practices.

About 5\% of German agricultural land has been deep ploughed at least once in history. Considering that many of today's landowners are highly sceptical about deep ploughing (Frelih-Larsen et al. 2018), this share seems relatively large. Many deep-ploughed sites are clustered in northwest Germany close to the Dutch-German border. Most of them are a legacy of the "Emslandplan" - a land reclamation act that was passed by the German parliament shortly after the Second World War with the goal of converting heathland and peatland in northwest Germany into agricultural land (Eggelsmann 1979). This was achieved by draining the peatland, then partly excavating the peat and finally deep ploughing. Massive steam engines were used to deep plough the remaining organic layer and the Podzol soil underneath down to $2 \mathrm{~m}$ depth with the goal of (i) improving drainage by shattering cemented ironpans (ortstein), and (ii) mixing the organic layer with sand to improve the trafficability and workability of the affected sites (Eggelsmann 1979). High $\mathrm{C} / \mathrm{N}$ ratios and a sandy soil texture were key parameters for predicting deep ploughing. This confirms that most deep-ploughed sites were former heathland or peatlands. Apart from northwest Germany, deep-ploughed sites were also clustered in wine-growing regions along the Rhine and Mosel. In German viticulture, deep manual digging $(>50 \mathrm{~cm}$ ) was performed for centuries (Mollenhauer 2014). Since the start of industrialisation, viticultural soil is often deep ploughed when renewing vineyards (Coulouma et al. 2006). Apart from viticulture, deep ploughing is rarely practised on agricultural land in Germany today.

\section{Biopores}

Compacted soil can be meliorated biologically by increasing the number of biopores. This can only be achieved indirectly, either by increasing the number of anecic earthworms or by including plant species with large taproots in crop rotations. Earthworm abundance in cropland has been shown to depend on aeration, texture and $\mathrm{pH}$, with the highest abundances observed in well-aerated soils of silty texture and $\mathrm{pH}$ values from 5 to 7.4 (Curry 2004). Alfalfa (Medicago sativa L.) and other taprooted crops, which have been promoted for biopore-enhancing management (Han et al. 2015), require similar growing conditions as earthworms (Hartmann et al. 2014). Physicochemical soil properties, which provide optimal growing conditions for anecic earthworms and taprooted plants, can also benefit the structural stability of biopores. In well-aerated loess soils, relict earthworm burrows have been shown to be stable for decades or even centuries (Don et al. 2008). In non-loess soil, biopore stability might be much lower. In extremely sandy soils, burrows might collapse faster than in silt due to low adhesion forces among sand particles (Schrader and Zhang 1997). In heavy clay soils, seasonal shrinking and swelling of clay minerals could potentially have a negative impact on biopore stability. Well-aerated soils also show no stagnant water or groundwater that could induce the collapse of biopores (Bottinelli et al. 2010). Hence, biopore abundance should be highest in non-acidic, well-aerated loess soils because they provide optimal environments for biopore formation and stability. This is in perfect agreement with the results obtained in the present study. These results confirmed that biopore abundance is closely linked to soil texture and $\mathrm{pH}$. Furthermore, the results suggest a positive correlation between biopores and SOC. Increased SOC levels could be earthwormderived, e.g. in the form of burrow linings (Don et al. 2008), but also root-derived and resulting from increased litter inputs in biopore-containing soils. Enhanced rooting might also explain the relatively wide $\mathrm{C} / \mathrm{N}$ ratio, which correlates with biopore abundance in $30-50 \mathrm{~cm}$ depth. Finally, there could be positive feedbacks between rooting, biopore formation and SOC contents. Anecic earthworms are highly responsive to inputs of fresh litter (Curry 2004). Decaying plant roots could provide such litter and stimulate earthworm burrowing along with SOC accumulation.

Land use had no effect on biopores in subsoils. This was surprising since the abundance of anecic earthworms is typically much higher in grassland than in cropland (Spurgeon et al. 2013). It is hypothesised that in cropland, the absence of biopore formation by earthworms is compensated for by taprooted crops such as canola (Brassica napus L.). Field workers reported that 
canola formed biopores that were used preferentially by roots of subsequent cereal crops to grow into the subsoil (Schemschat, Bernd; pers. communication). In recent decades, the area under canola has risen from $<0.1 \%$ of German cropland in the 1950 s to $11 \%$ in 2016 (Destatis 2017; Goldhofer et al. 2014a). The rising popularity of canola may have led to increased biopore formation in cropland. However, this remains speculative since in the present study there were no data on the origin and age of the biopores, hence it was not possible to distinguish between earthworm-derived and taprootderived biopores. The absence of effects of land use on biopore abundance could also be explained by the dependence of land use on soil types and associated stabilities of biopores. Anoxic soils with high groundwater tables and low biopore stability were preferentially used as grassland (Fig. 2), while on loess soils with high biopore stability grassland use was negligible and cropland dominated.

To the best of our knowledge, the German Agricultural Soil Inventory is the first inventory to provide information on biopores in agricultural soils at national scale. Large observation numbers allowed biopore data to be evaluated and trends elucidated despite the fact that biopore abundance was only estimated visually by soil scientists. The regional clustering of biopores based on soil types suggests that successful melioration of densely-packed soil layers by means of biopores is restricted to loamy soils with high amounts of silt and little sand, low rock fragment contents, $\mathrm{pH}$ values $>5$ and well-aerated sites.

\section{Perspectives}

Subsoils can offer high stocks of water and nutrients for plants. In the past, many efforts were made to improve the plant availability of these resources. However, data derived from the German Agricultural Soil Survey suggests that at more than half of German agricultural land access to subsoil remains restricted (Schneider and Don 2019). This hampers agricultural productivity already today and, considering alarming climate change scenarios, is likely to limit the former even more in the future. Upcoming management of agricultural land with RRLs should be based upon the wealth of past experiences. Positive effects of deep tillage on yield, which were observed in previous research trials (Schneider et al. 2017), were often not confirmed in practice because of traffic induced recompaction of mechanically loosened soil. Mixing loosened subsoil with organic materials may stabilize the disturbed soil structure and improve the plant-availability of subsoil resources on the long term (Jayawardane et al. 1995). For German agricultural land, potential benefits (productivity, carbon sequestration etc) and hazards (nitrate leaching etc) of furrowwise loosening and deep mixing of organic matter are currently investigates (https://www.bonares.de/soil3). Cultivation of alfalfa and other tap-rooted crops provide a biological alternative to mechanical deep tillage and can improve the plant-availability of water and nutrients in compacted subsoils. Despite of this knowledge, the current share alfalfa in crop rotations is only minor because economic barriers limit its uptake (FrelihLarsen et al. 2018). Financial incentives could help to overcome these barriers.

\section{Conclusions}

Melioration has been carried out on $73 \%$ of German agricultural soils in order to improve plant-growing conditions. In most cases, it was not only aimed at facilitating deeper rooting, but also at improving infiltration (deep tillage), aeration (drainage), nutrient availability (liming of acid soils) as well as workability and trafficability (drainage). Compacted plough pans can be meliorated by deep chiselling if the soil is dry enough. However, as shown by Schneider and Don (2019), soil compactness was most severe at the maximum sampling depth of 70-100 cm. Below $50 \mathrm{~cm}$, mechanical deep chiselling is barely effective, but biopores could still enhance rooting. Generally, biopore-promoting management can be recommended for all except sandy, acid, anoxic and gravelly soils. Deep ploughing used to be a popular technique to break up ironpans in Podzols. Today, the area extent of German agricultural soils with ironpans is negligible and the use of deep ploughing is restricted to viticultural areas. The relatively large proportion of German agricultural land with permanently anoxic subsoils due to high groundwater tables could be meliorated by improved drainage, while extreme soil acidity could be meliorated by improved liming practices. However, in view of the costs of installing and maintaining drainage systems (especially in lowlands with a high groundwater table and little slope) and costs of liming, many farmers prefer to adapt to impaired growing conditions by using land extensively (i.e. as grassland). On sites with shallow bedrocks and/or high 
rock fragment contents, grassland use is often the only management option possible.

Acknowledgements This study was conducted within the BonaRes research project Soil3 (grant number 031B0515E) funded by Germany's Federal Ministry of Education and Research (BMBF). The German Agricultural Soil Inventory is funded by the Federal Ministry of Food and Agriculture (BMEL). We thank Christopher Poeplau, Catharina Riggers, Tamme de Vries, Sofia Heukrodt, Fabian Kalks, Ali Sakhaee and the anonymous reviewers for providing feedback on an earlier version of this manuscript.

Open Access This article is distributed under the terms of the Creative Commons Attribution 4.0 International License (http:// creativecommons.org/licenses/by/4.0/), which permits unrestricted use, distribution, and reproduction in any medium, provided you give appropriate credit to the original author(s) and the source, provide a link to the Creative Commons license, and indicate if changes were made.

\section{References}

AD-HOC-AG Boden (2005) Bodenkundliche Kartieranleitung, 5. Auflage. Schweizerbart, Stuttgart

Alcántara V, Don A, Well R, Nieder R (2016) Deep ploughing increases agricultural soil organic matter stocks. Glob Chang Biol 22:2939-2956

Bechtle W (1985) Erfahrungen und Ergebnisse aus Tieflockerungen in Baden-Württemberg. Schriftenreihe des Deutschen Verbands für Wasserwirtschaft und Kulturbau eV (DVWK) 70:37-74

BMEL (2017) Daten und Fakten. Land-, Forst- und Ernährungswirtschaft mit Fischerei und Wein- und Gartenbau. Bundesministerium für Ernährung und Landwirtschaft, Berlin

BMWi (2018) Jahresbericht der Bundesregierung zum Stand der Deutschen Einheit 2018. Bundesministerium für Wirtschaft und Energie, Berlin

Bottinelli N, Henry-des-Tureaux T, Hallaire V, Mathieu J, Benard Y, Duc Tran T, Jouquet P (2010) Earthworms accelerate soil porosity turnover under watering conditions. Geoderma 156 : $43-47$

Breiman L (2001) Random forests. Mach Learn 45:5-32

Chawla NV, Bowyer KW, Hall LO, Kegelmeyer WP (2002) SMOTE: synthetic minority over-sampling technique. J Artif Intell Res 16:321-357

Coulouma G, Boizard H, Trotoux G, Lagacherie P, Richard G (2006) Effect of deep tillage for vineyard establishment on soil structure: a case study in southern France. Soil Tillage Res 88:132-143

Cresswell H, Kirkegaard J (1995) Subsoil amelioration by plantroots - the process and the evidence. Soil Research 33:221239

Curry JP (2004) Factors affecting the abundance of earthworms in soils. Earthworm ecology 9:113
Destatis (2017) Land- und Forstwirtschaft. Statistisches Jahrbuch Deutschland und Internationales. Bundesministerium für Ernährung und Landwirtschaft. www.destatis.de/jahrbuch. Accessed 19 Feb 2019

Diepolder M, Hartmann S, Gehring K, Zellner M, Demmel M (2014) Dauergrünland. In: Doleschel P, Frahm J (eds) Landwirtschaftlicher Pflanzenbau. BLV Buchverlag, München

Don A, Steinberg B, Schöning I, Pritsch K, Joschko M, Gleixner G, Schulze E-D (2008) Organic carbon sequestration in earthworm burrows. Soil Biol Biochem 40:1803-1812

Eggelsmann R (1979) Vom Dampfpflug zum Tiefkulturpflug -Entwicklung und Einsatz. Z f Kulturtechnik und Flurbereinigung 20:99-112

EU (2013) Regulation (EU) no 1307/2013 of the European Parliament and of the council of 17 December 2013 establishing rules for direct payments to farmers under support schemes within the framework of the common agricultural policy and repealing council regulation (EC) no 637/2008 and council regulation (EC) no 73/2009. Off J Eur Communities 347:608-670

Fawcett T (2006) An introduction to ROC analysis. Pattern Recogn Lett 27:861-874

Frelih-Larsen A, Hinzmann M, Ittner S (2018) The 'Invisible'subsoil: an exploratory view of societal acceptance of subsoil management in Germany. Sustainability 10:3006

Goldhofer H, Aigner A, Wendland M, Gehring K, Zellner M (2014a) Ölfruchtanbau. In: Doleschel P, Frahm J (eds) Landwirtschaftlicher Pflanzenbau. BLV Buchverlag, München

Goldhofer H, Nickle U, Gehring K, Weigand S, Demmel M, Weber A, Hartle L, Herz M, Eder J, Brandhuber R, Wendland M, Zellner M (2014b) Getreide- und Maisbau. In: Doleschel P, Frahm J (eds) Landwirtschaftlicher Pflanzenbau. BLV Buchverlag, München

Greenwell BM (2017) Pdp: an R package for constructing partial dependence plots. R Journal 9:421-436

Han E, Kautz T, Perkons U, Lüsebrink M, Pude R, Köpke U (2015) Quantification of soil biopore density after perennial fodder cropping. Plant Soil 394:73-85

Hartmann S, Gehring K, Zellner M (2014) Feldfutteranbau. In: Doleschel P, Frahm J (eds) Landwirtschaftlicher Pflanzenbau. BLV Buchverlag, München

Hastie T, Tibshirani R, Friedman J (2009) The elements of statistical learning. Data mining, inference, and prediction. Springer, New York

Hobley E, Wilson B, Wilkie A, Gray J, Koen T (2015) Drivers of soil organic carbon storage and vertical distribution in eastern Australia. Plant Soil 390:111-127

Hothorn T, Bühlmann P, Dudoit S, Molinaro A, Van Der Laan MJ (2005) Survival ensembles. Biostatistics 7:355-373

Jacobs A, Flessa H, Don A, Heidkamp A, Prietz R, Dechow R, Gensior A, Poeplau C, Riggers C, Schneider F, Tiemeyer B, Vos C, Wittnebel M, Müller T, Säurich A, Fahrion-Nitschke A, Gebbert S, Hopstock R, Jaconi A, Kolata H, Lorbeer M, Schröder J, Laggner A, Weiser C, Freibauer A (2018) Landwirtschaftlich genutzte Böden in Deutschland Ergebnisse der Bodenzustandserhebung. Johann Heinrich von Thünen-Institut, Braunschweig

Jakobs I, Schmittmann O, Schulze Lammers P (2017) Short-term effects of in-row subsoiling and simultaneous admixing of 
organic material on growth of spring barley (H. vulgare). Soil Use Manag 33:620-630

Jayawardane NS, Blackwell J, Kirchhof G, Muirhead WA (1995) Slotting - a deep tillage technique for ameliorating sodic, acid and other degraded subsoils and for land treatment of waste. In: BA Stewart, NS Jayawardane (eds) subsoil management techniques. CRC Press, Boca Raton

Kautz T (2015) Research on subsoil biopores and their functions in organically managed soils: a review. Renew Agric Food Syst 30:318-327

Kirkegaard JA, Lilley JM, Howe GN, Graham JM (2007) Impact of subsoil water use on wheat yield. Aust J Agric Res 58: 303-315

Klepper B (1992) Development and growth of crop root systems. In: Hatfield JL, Stewart BA (eds) Limitations to plant root growth. Springer, New York

Kuhn M (2018) Caret: classification and regression training. R package version 6.0-80 with contributions from Jed Wing, Steve Weston, Andre Williams, Chris Keefer, Allan Engelhardt, Tony Cooper, Zachary Mayer, Brenton Kenkel, the R Core Team, Michael Benesty, Reynald Lescarbeau, Andrew Ziem, Luca Scrucca, Yuan Tang, can Candan and Tyler Hunt. https://www.CRANR-projectorg/package=caret

Kuhn M, Johnson K (2013) Applied predictive modeling. Springer, New York

Lindner H, Frielinghaus M, Hess H, Kleu B, Schulte KH, Schultz D, Thiere J (1972) Steigerung der Erträge und Erhöhung der Ertragssicherheit durch Tieflockerung verdichteter Böden. Feldwirtschaft 6:267-270

Lynch JP, Wojciechowski T (2015) Opportunities and challenges in the subsoil: pathways to deeper rooted crops. J Exp Bot 66: 2199-2210

Materechera SA, Alston AM, Kirby JM, Dexter AR (1992) Influence of root diameter on the penetration of seminal roots into a compacted subsoil. Plant Soil 144:297-303

Menardi G, Torelli N (2014) Training and assessing classification rules with imbalanced data. Data Min Knowl Disc 28:92-122

Mollenhauer K (2014) Tiefenbearbeitung. In: Blume HP, FelixHenningsen P, Frede H-G, Guggenberger G, Horn R, Stahr K (eds) Handbuch der Bodenkunde. Wiley, Weinheim

Nakazawa M (2018) Fmsb: functions for medical statistics book with some demographic data. $\mathrm{R}$ package version 0.6.3. https://www.CRANR-projectorg/package $=\mathrm{fmsb}$

Patt H, Gonsowski P (2011) Landwirtschaftlicher Wasserbau. Grundlagen, Gestaltung von wasserbaulichen Bauwerken und Anlagen. Springer, Berlin, Heidelberg, Wasserbau

R Core Team (2018) R: a language and environment for statistical computing. R Foundation for Statistical Computing, Vienna

Renger M (1974) Bodenkundliche Kriterien für die Auswahl von Verfahren der Tiefenbearbeitung auf meliorationsbedürftigen Standorten. Landbauforschung Völkenrode, Sonderheft 24: $1-14$

Richard JE, Misener GC, Milburn P, McMillian LP (1995) Incorporation of limestone into naturally compacted subsoil during deep-ripping. Soil Tillage Res 36:21-32
RStudio Team (2016) RStudio: integrated development environment for R. RStudio, Inc., Boston

Schiedung M, Tregurtha C, Beare MH, Thomas S, Don A (2019) Deep soil flipping increases carbon stocks of New Zealand grasslands. Glob Chang Biol. https://doi.org/10.1111 /gcb. 14588

Schmid G, Borchert H, Weigelt H (1972) Bodenmelioration durch Tiefendüngung und Tiefenlockerung mit Ausgleichsdüngung. Zeitschrift für Kulturtechnik und Flurbereinigung 13:354-372

Schneider F, Don A (2019) Root restricting layers in German agricultural soils. Part I: extent and cause. Plant Soil. https://doi.org/10.1007/s11104-019-04185-9

Schneider F, Don A, Hennings I, Schmittmann O, Seidel SJ (2017) The effect of deep tillage on crop yield - what do we really know? Soil Tillage Res 174:193-204

Schrader S, Zhang H (1997) Earthworm casting: stabilization or destabilization of soil structure? Soil Biol Biochem 29:469475

Shainberg I, Sumner ME, Miller WP, Farina MPW, Pavan MA, Fey MV (1989) Use of gypsum on soils: a review. In: Stewart BA (ed) Advances in soil science. Springer, New York

Shaxson F, Barber R (2003) Optimizing soil moisture for plant production: the significance of soil porosity. FAO, Rome

Spurgeon DJ, Keith AM, Schmidt O, Lammertsma DR, Faber JH (2013) Land-use and land-management change: relationships with earthworm and fungi communities and soil structural properties. BMC Ecol 13:46

Strobl C, Boulesteix A-L, Zeileis A, Hothorn T (2007) Bias in random forest variable importance measures: illustrations, sources and a solution. BMC Bioinformatics 8:25

Strobl C, Boulesteix A-L, Kneib T, Augustin T, Zeileis A (2008) Conditional variable importance for random forests. BMC Bioinformatics 9:307

Sumner ME (1995) Amelioration of subsoil acidity with minimum disturbance. In: Jayawardane NS, Stewart BA (eds) Subsoil Management Techniques. CRC Press, Boca Raton

Tang C, Rengel Z, Diatloff E, Gazey C (2003) Responses of wheat and barley to liming on a sandy soil with subsoil acidity. Field Crop Res 80:235-244

van Vliet J, de Groot HLF, Rietveld P, Verburg PH (2015) Manifestations and underlying drivers of agricultural land use change in Europe. Landsc Urban Plan 133:24-36

Wendland M, Demmel M, Neser S (2014) Pflanzenernährung und Düngung. In: Doleschel P, Frahm J (eds) Landwirtschaftlicher Pflanzenbau. BLV Buchverlag, München

Wickham H (2016) ggplot2: elegant graphics for data analysis. Springer, New York

Wilson O (1996) Emerging patterns of restructured farm businesses in Eastern Germany. GeoJournal 38:157-160

Publisher's note Springer Nature remains neutral with regard to jurisdictional claims in published maps and institutional affiliations. 